\title{
Pedicle preservation in a Silurian rhynchonelliformean brachiopod from Herefordshire, England: soft-tissue or an artefact of interpretation?
}

\author{
Michael G. Bassett ${ }^{1}$, Leonid E. Popov ${ }^{1}$ and Eva Egerquist ${ }^{2}$ \\ ${ }^{1}$ Department of Geology, National Museum of Wales, Cathays Park, Cardiff CF10 3NP, UK \\ E-mail: mike.bassett@museumwales.ac.uk
}

${ }^{2}$ Department of Earth Sciences, Palaeobiology, Uppsala University, Norbyvagen 22, SE 752 36, Uppsala, Sweden

\begin{abstract}
The interpretation of pedicle soft tissue preservation in a unique brachiopod specimen of Wenlock (Silurian) age from Herefordshire, western England, is re-assessed. Bethia serraticulma, assigned originally to the Orthida, is more probably a member of the Strophomenida (Plectambonitoidea). The supposed pedicle structure is more plausibly a weakly mineralised pedicle sheath, which is a common morphological and functional development in the early ontogeny of a number of Palaeozoic brachiopod lineages.
\end{abstract}

KEY WORDS: Bethia, Plectambonitoidea, phylogeny, taxonomy

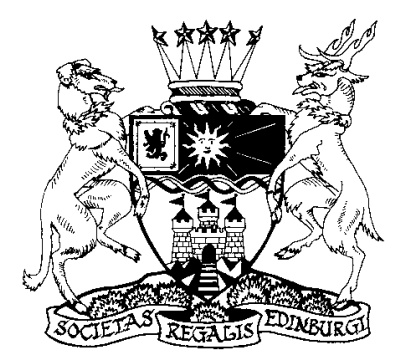

The recent record of a Silurian (Wenlock) age rhynchonelliformean brachiopod from the Herefordshire KonservatLagerstatte of western England (Briggs et al. 1996) purports to recognise the preservation of a robust, ridged pedicle with distal rootlets, together with a lophophore and other soft tissue structures (Sutton et al. 2005). The authors assign the single specimen questionably to the Order Orthida and describe it as a new genus and species, Bethia serraticulma. The present paper re-evaluates the interpretation of these various structures and also the taxonomic assignment of the specimen. Trace fossils related to rhynchonelliformean brachiopod pedicle attachment are well known from Mesozoic and Cenozoic deposits (Bromley \& Surlyk 1973), but all other published reports of fossilisation of the pedicle are confined to the lingulides (Class Linguliformea) (Davidson 1866; Walcott 1888; Jin et al. 1993). This may be a reflection of different fossilisation potential of organic tissue in the pedicle of the two major brachiopod clades. The pedicle of Recent linguliformeans is an outgrowth of the ventral part of the posterior body wall, confined within the ventral valve and enclosing a coelomic space. The outer cuticle of the pedicle contains fibres of chitin underlain by a layer of connective tissue with collagen fibres and then by a layer of dermal muscles (Williams et al. 1997). By contrast, the pedicle of Recent rhynchonelliformeans developed from the posterior part of the larval pedicle lobe, with no direct relationship to either valve; it lacks a coelom, but instead its core is composed of collagen fibres and in part of cartilage-like tissue (Williams et al. 1997; Stricker \& Reed 1985b). Such cartilage-like tissue is also present in the lophophore of Recent rhynchonelliformeans (Williams et al. 1997). In juvenile shells of the Ordovician orthide Paralenorthis orbicularis (Fig. lg-i) there is a distinct pedicle collar in the umbonal part of the delthyrial cavity that suggests a similar morphology of the proximal pedicle region to that of Recent rhynchonelliformeans. This may suggest that characters of the pedicle in extant rhynchonelliformean taxa are advanced and evolved relatively late in phylogeny, but were already present in the orthides that places them distantly from Bethia.

Crucial to the present authors' reinterpretation of Bethia is the fact that some groups of early Palaeozoic strophomenate rhynchonelliformeans evolved a calcified pedicle sheath in early ontogeny as part of a distinct attachment structure (Popov et al. 2007; Bassett et al. 2008). It is argued that the so-called 'pedicle' of Bethia serraticulma is in a fact a weakly mineralised sheath and the animal itself is more probably not an orthide but is a strophomenide, most probably belonging to an already known plectambonitoidean genus.

\section{Why not an orthide?}

British Silurian orthide brachiopods are well known morphologically and taxonomically, including Wenlock age faunas closely comparable with the age of the Herefordshire deposits (Davidson 1866-71; Bassett 1970-77). Without exception, all known orthide genera (comprising impunctate Orthidina and endopunctate Dalmanellidina) in these strata have distinctive radial ornament with well preserved impressions of setal follicles along the shell margin indicative of the original presence of setae. Bethia is diagnosed as lacking any component of radial ornament. Juvenile shells of the known Wenlock orthide groups are usually ventribiconvex and lack a ventral sulcus, but can be weakly carinate. They all have an open delthyrium or at most a small apical plate, but no complete delthyrial covers. In Bethia, even without information on the interiors of both valves and of shell structure, the presence of incipient deltidial plates (as per the original diagnosis), together with the absence of any evidence of the presence of setae, suggests a difference from all known Silurian orthides at the superfamily, or even more probably higher taxonomic level. 

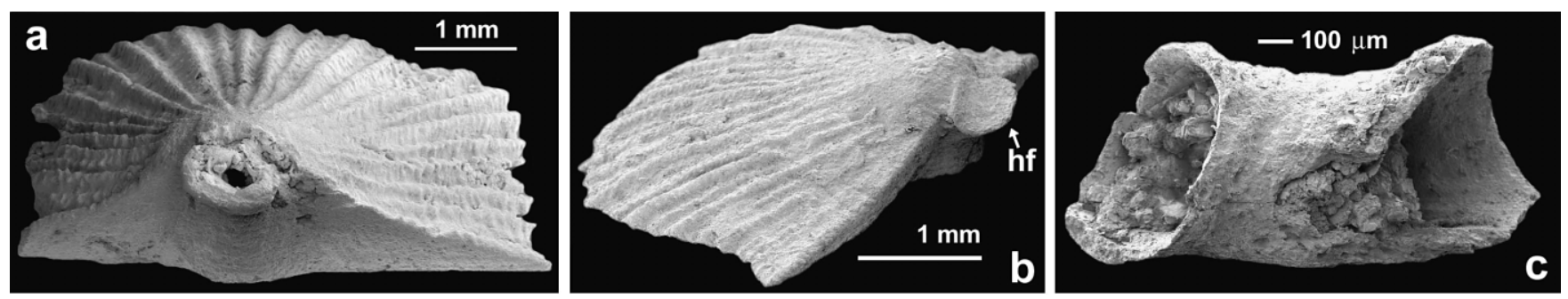
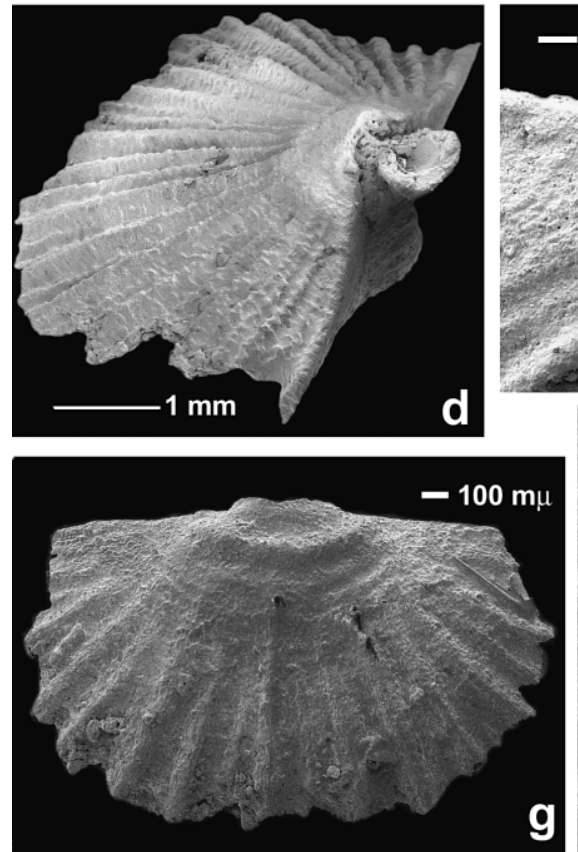
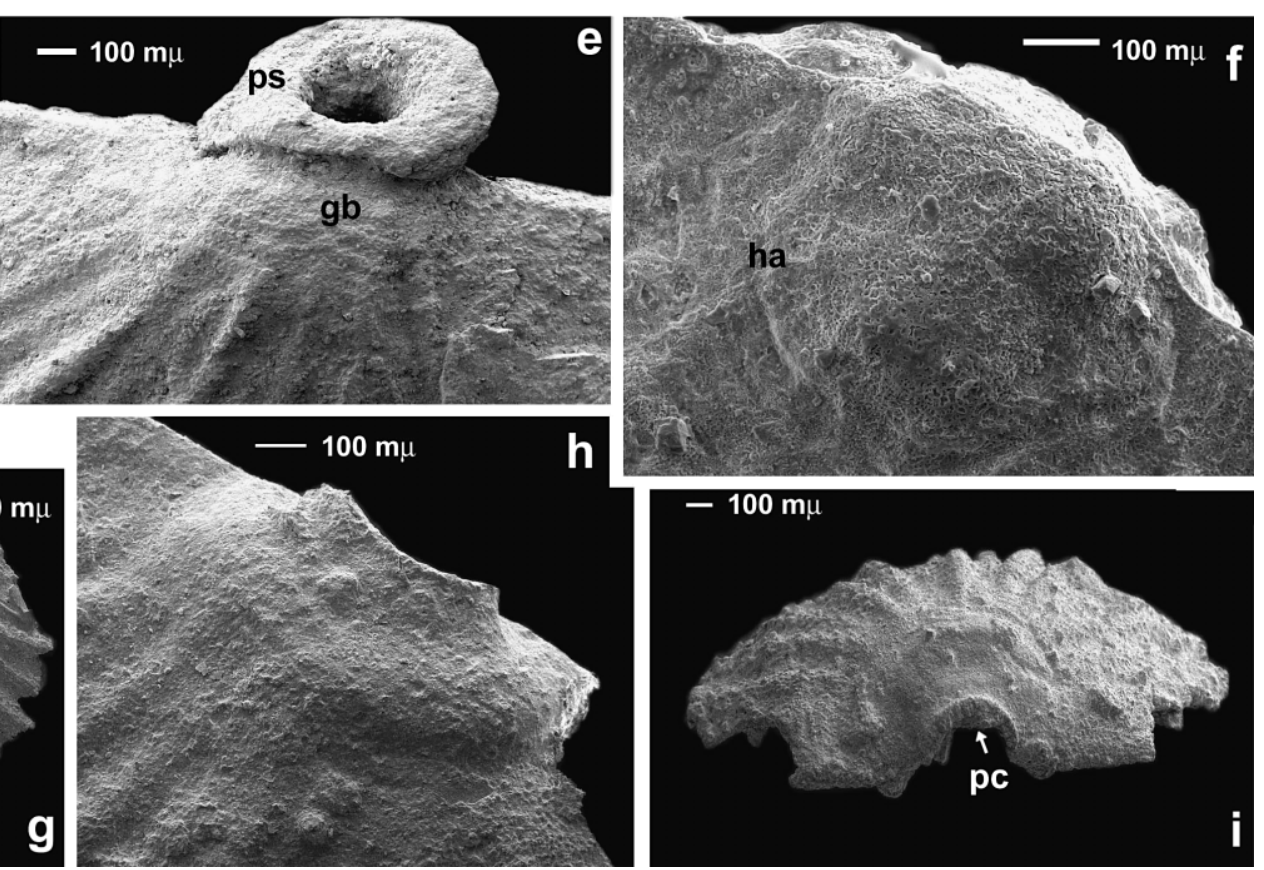

Figure 1 (a)-(f) Antigonambonites planus (Pander), Middle Ordovician, Volkhovian, Volkhov Formation, St Petersburg Region, Russia: (a), (d) NMW 2001.39G.530, Volkhov River, east side downstream of Simankovo village; oblique posterior and lateral views of ventral valve showing pseudodeltidium and pedicle sheath; (b) PMU In 558, Tosna River near Gertovo village; oblique lateral view of ventral valve of juvenile specimen showing umbonal area with a fully grown pedicle sheath with holdfast (hf); (c) PMU In 549, Lava River opposite Gorodishche village, broken pedicle sheath; (e) PMU In 557, Tosna River near Gertovo village; umbonal part of juvenile ventral valve showing open distal part of pedicle sheath (ps) and concentric growth bands (gb) on the umbonal region around the sheath; (f) NMW 2001.39G.529, Babino quarry, east side of Vokhov River, umbonal region of juvenile dorsal valve showing distinct halo (ha) surrounding the first-formed shell and irregular mosaic of flattened fibres of secondary shell covering the area. (g-i) Paralenorthis orbicularis (Pander), Middle Ordovician, Volkhovian, Volkhov Formation, St Petersburg Region, Russia: (g)-(h) phosphorite quarry west of Kingisepp: (g) NMW 2001.39G.544, posterior view of juvenile ventral valve showing delthyrial opening and pedicle collar; (h) NMW 2001.39G.545, juvenile ventral valve exterior; (i) NMW 2001.39G.543, east side of Volkhov River north of Simankovo village, umbonal part of ventral valve showing the area occupied by pedicle collar $(\mathrm{pc})$. $(\mathrm{NMW})=$ National Museum of Wales, Cardiff; $(\mathrm{PMU})=$ Palaeontological Museum (Museum of Evolution), Uppsala University, Sweden.

\section{Alternative interpretation of affinities}

One original main reason (Sutton et al. 2005) for rejecting an affinity of Bethia with strophomenates was the presence of a delthyrial opening lacking a pseudodeltidium. However, incipient deltidial plates are reported, describing the delthyrium as being 'bounded dorsally by two spine-like projections of the ventral valve converging medially'. In morphological and functional expression, these 'projections' are far more likely to be part of a cover merging below the structure described as the pedicle. The alternative interpretation is that the structure described as the pedicle in Bethia is in fact weakly calcified as a cylindrical stalk protruding through the delthyrial opening and representing a combination of a pedicle sheath and incipient pseudodeltidium of a juvenile strophomenate brachiopod. There is considerable evidence for the development of such sheaths and associated structures in the early ontogeny of Strophomenata.

\section{Pedicle sheath in strophomenates}

From the supplementary information supporting the original publication (Sutton et al. 2005) of Bethia serraticulma, rejection of a strophomenate affinity included a view that 'all strophomenate brachiopods, with the exception of the clitambonitidines, possess a pseudodeltidium; the pedicle foramen, when present, is invariably apical or supra-apical'. However, such a statement relies largely on data from observations on brachiopod ontogeny published in some cases well over half a century ago (Beecher \& Clarke 1892; Arber 1940), but which are somewhat lacking precision in description and interpretation of various structures. SEM studies by the present authors of the early ontogeny of various Palaeozoic brachiopod groups no longer support the earlier interpretations (see also Freeman \& Lundelius 2005; Popov et al. 2007; Bassett et al. 2008). In the present interpretations (Figs 1-3) examples from plectambonitoideans and polytoechioideans are used, but it is emphasised 

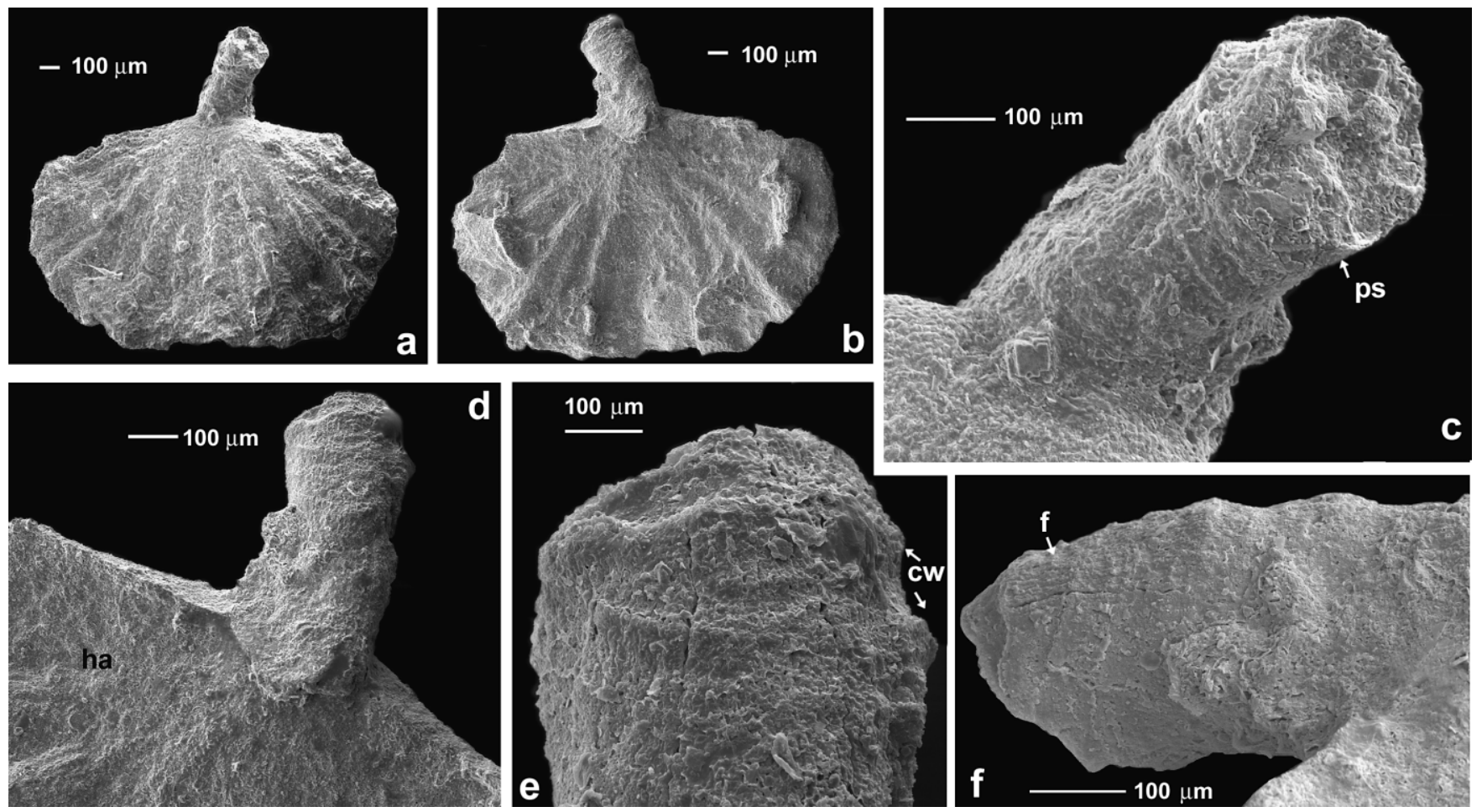

Figure 2 Ujukella fastignata (Rubel), Middle Ordovician, Volkhovian, Volkhov Formation, Saka Member, mud mound in western side of Babino Quarry, St Petersburg Region, Russia; NMW 2001.39G.528: (a)-(b) ventral and dorsal views of conjoined valves; (c) ventral umbonal area with long pedicle sheath (ps); (d) dorsal view of umbonal area including first formed shell (ha-halo) and pedicle sheath, pseudodeltidium not yet developed; (e) enlarged distal part of pedicle sheath showing distinct irregular concentric wrinkles similar to the those of Bethia; (f) oblique lateral view of pedicle sheath showing arrangement of fibres (f) and irregular coarse concentric wrinkles representing growth bands. NMW= National Museum of Wales, Cardiff.

that homologous structures have also been studied in a considerably wider range of Ordovician and Silurian plectambonitoideans, strophomenoideans, chonetoideans and orthotetoideans. Brunton (1964) described the same features in orthotetoideans and in Carboniferous productoideans, and Freeman \& Lundelius (2005) have illustrated their presence in the immediate post-larval development of triplesioideans and a range of strophomenate taxa. In all these cases the morphology of the tubular structure referred to as the pedicle sheath is essentially as illustrated in figure 319 of Williams et al. (1997), although as noted below, it does not necessarily imply a similar relationship with the pedicle itself, but that separate matter is discussed elsewhere (Popov et al. 2007; Bassett et al. 2008).

A pedicle sheath of similar morphology, size and position in relation to the pseudodeltidium and ventral umbo is present in juvenile shells of the earliest known plectambonitoideans, in particular the Middle Ordovician Ujukella fastignata from the St Petersburg region, Russia (Fig. 2). The illustrated shell is about $2.9 \mathrm{~mm}$ long and has a long, posteroventrally directed, robust, cylindrical pedicle sheath about $500 \mu \mathrm{m}$ long and about $270 \mu \mathrm{m}$ in diameter, situated behind the umbo and probably fused with the incipient pseudodeltidium which is not yet fully differentiated. The sheath is ornamented by irregular concentric rings indicative of accretionary growth, as can be concluded from the arrangement of fibres of secondary shell (Fig. $2 \mathrm{e}, \mathrm{f})$. These relatively coarse, irregular growth bands closely resemble the irregular concentric wrinkling reported on the 'pedicle' of Bethia and there is good reason to interpret the structures of the illustrated Ujukella as being of similar origin and nature. The umbonal region of the ventral valve of plectambonitoideans bears a distinct median cleft similar to the 'sulcus' of Bethia (Fig. 3i, j). There is no gap between the valves in Ujukella along the entire posterior margin (Fig. 2d), and the delthyrium and notothyrium are completely covered at all growth stages. Even in some plectambonitoideans (e.g. Eoplectodonta) which are usually considered as lacking deltidial structures, there is in fact a small apical pseudodeltidium visible in juvenile shells (Fig. 3e, f), but which is normally masked by secondary shell growth in adult specimens; it is apparent that this deltidial opening is not functional, being occupied by the cardinal process and chilidium. The pedicle sheath in all studied shells of Eoplectodonta is invariably broken along radially arranged fibres of secondary shell surrounding the umbonal perforation (Fig. 3c, f), and the ventral valve has a distinct median cleft anterior to the umbo (Fig. 3f).

There is a similar pedicle sheath in early ontogenetic specimens of Jonesea sp. from the Silurian Eke Formation of Gotland, but this has a truncated conical shape with a diameter of the proximal end of only about $90 \mu \mathrm{m}$ (Fig. 3i, j). The brephic shell is about $300 \mu \mathrm{m}$ wide and also has a deep median cleft separating inflated lateral lobes and a small arched pseudodeltidium (Fig. 3j), closely similar to the structures in Eoplectodonta.

A pedicle sheath is also present in at least some taxa of the Order Billingsellida, which is considered as the ancestral stock of strophomenates (Williams et al. 1996), in particular in the Middle Ordovician Antigonambonites planus, which is interpreted as an advanced billingsellide (Family Polytoechiidae) (Popov et al. 2001, 2007). Its ventral umbonal area in juvenile valves has a short pedicle sheath, widening distally, with a diameter of $350-400 \mu \mathrm{m}$ near the umbo and about $750-900 \mu \mathrm{m}$ at its termination (Fig. la, b, d, e). As in Ujukella, this tube is situated immediately behind the ventral umbo, merges with the pseudodeltidium, and shows distinct signs of peripheral growth. It is open distally in juveniles but becomes tapered in larger shells, forming a distinct holdfast (Fig. 1c). The sheath is often broken in adult specimens of Antigonambonites and 'loose' sheaths are not uncommon in the sediment (Fig. la). 

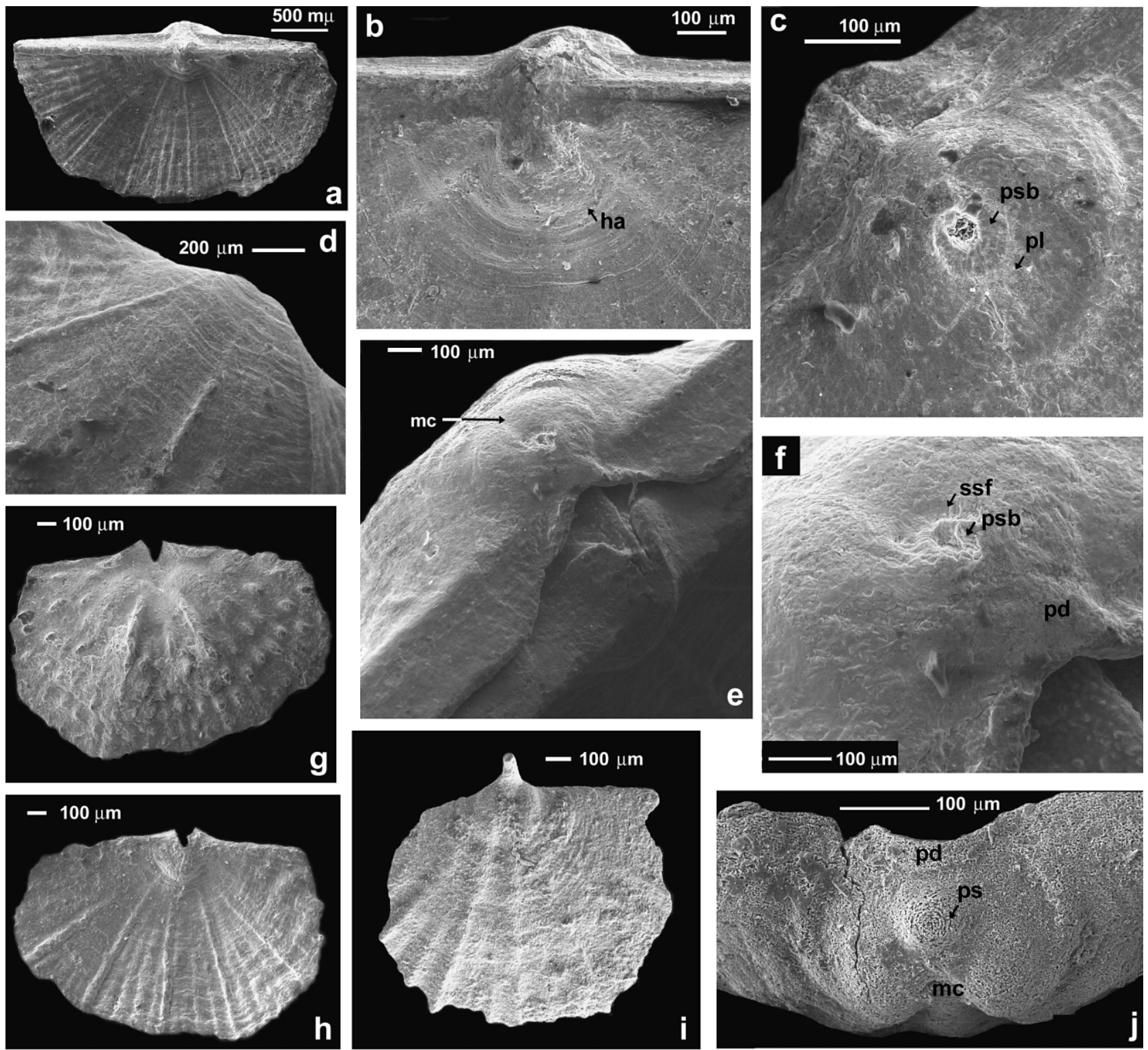

e
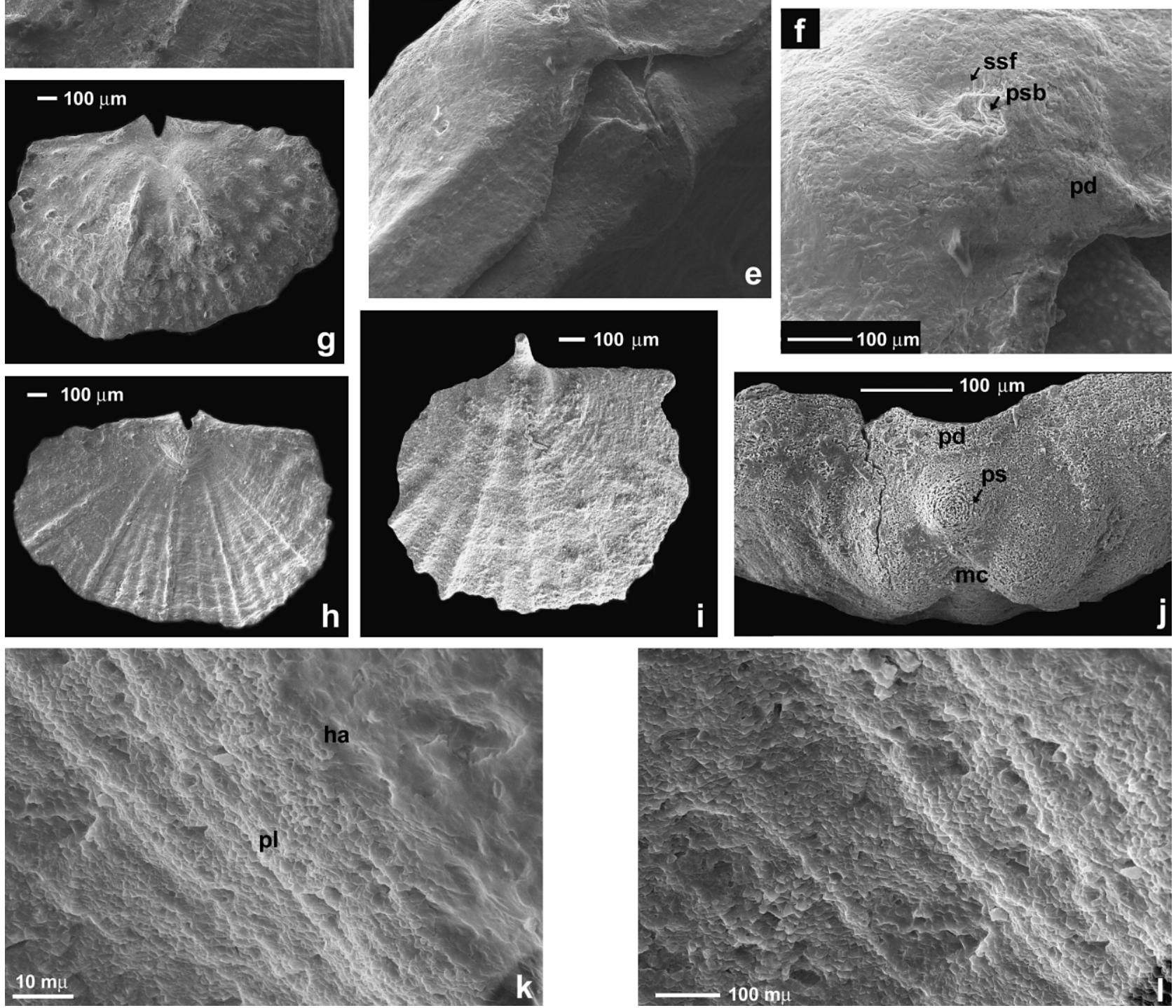

Figure 3 (a)-(h), (k) (1) Eoplectodonta duvalii (Davidson), Silurian, Wenlock, upper Slite Group, Svarvare-1: (a)-(c), (k) (l) NMW 2007.8G.1: (a) dorsal exterior; ( b) dorsal umbo; (c) ventral umbo with base of broken pedicle sheath and with characteristic radial arrangement of secondary shell fibres, shallow median cleft anterior to pedicle sheath base, and patches of microgranular primary shell layer (pi) surrounding ventral umbonal perforation (base of broken pedicle sheath $(\mathrm{psb})$; $(\mathrm{k})$ characters of transition from the first formed dorsal shell to adult shell with microgranular primary shell layer outside halo (ha); (l) surface of adult shell with growth lines and well preserved microgranular primary shell layer (pl); (d)-(f) NMW 2007.8G.2: (d) ventral umbonal part of juvenile shell, showing primary ribs and parvicostellae developed at considerable distance (more than $1 \mathrm{~mm}$ ) from the umbo; (e) oblique posterior view of umbonal part of juvenile shell showing small apical pseudodeltidium, cardinal process and chilidial plates; (f) enlarged umbonal perforation (psb) surrounded by fibres of secondary shell (ssf), and pseudodeltidium (pd); (g), (h) NMW 2007.8G.3: interior and exterior of juvenile dorsal valve showing median and pair of side septa, denticulate hinge not yet developed. (i), (j) Jonesea sp. NMW 2007.8G.4, Silurian, Ludlow, Eke Formation, Gotland, Sweden: (i) exterior of juvenile shell showing long pedicle sheath (ps); (j) posterior view of umbonal area showing median cleft (mc) similar to the 'sulcus' of Bethia, and small pseudodeltidium merged with base of pedicle sheath. 
There is little doubt that the pedicle sheaths of Ujukella and Antigonambonites are homologous structures, and their presence in both taxa can be considered as a synapomorphy. Thus the apical foramen in the billingsellide and strophomenide brachiopods may represent the site of a broken pedicle sheath, which served as the initial attachment structure that developed soon after larval settlement.

The clear evidence of accretionary growth on the pedicle sheath of Ujukella and Antigonambonites and its association with the ventral valve suggest that the sheath was secreted by mantle, and thus cannot be interpreted as a homologue of the pedicle of extant rhynchonelliformeans (for further discussion, see also Popov et al. 2007). Moreover, the ventral umbonal area in both taxa preserves traces of peripheral growth immediately from the apex and there are no areas that can represent a protegulum and larval shell (Fig. le). By contrast, the first-formed shell and its boundaries are readily recognised in the dorsal valve as a semioval area $500-550 \mu \mathrm{m}$ wide (Fig. 1f). The dorsal first-formed shell of Antigonambonites lacks radial ornament and is surrounded by a halo about $20 \mu \mathrm{m}$ wide. There is a $150-200 \mu \mathrm{m}$-wide band outside the halo, bearing distinct concentric micro-ridges before radial ribs start to appear (Fig. 1f). The size of the dorsal first-formed shell is closely comparable with the diameter of the pedicle sheath, about $0.5 \mathrm{~mm}$ wide.

The maximum size of eggs in Recent rhynchonelliformean and craniiformean brachiopods with lecithotrophic larvae does not exceed $200 \mu \mathrm{m}$ (Williams et al. 1997) so that the protegulum, as the shell formed by the larval mantle, can hardly therefore exceed this size (Freeman \& Lundelius 1999). By contrast, the first formed-shell of Antigonambonites is at least twice as large and it lacks an area with microgranular structure characteristic of the protegulum of Recent rhynchonelliformeans (Stricker \& Reed 1985a), and is underlain by a fibrous secondary layer that more probably formed at later stages of growth when the outer mantle epithelium became fully differentiated and the secretory regime of the adult shell was established. In the Recent rhynchonelliformean Terebratalia transversa, secretion of the fully differentiated, adult shell begins on the fourth day after settlement, when juveniles are just $180 \mu \mathrm{m}$ long (Stricker \& Reed 1985a).

It is likely that the halo around the dorsal valve of the first-formed shell of Antigonambonites developed at the beginning of secretion of the fibrous secondary shell layer across the mantle. This is supported by the similar size of the proximal end of the pedicle sheath, marking the beginning of secretion of secondary shell in the ventral valve. The primary shell of strophomenates is very thin, composed of microgranular calcite (Fig. 31). It is rarely preserved in detail, possibly due to weak mineralisation. It is probable that the structure of the shell secreted following metamorphosis was similar to that of the primary layer of adult shells, and observed relief of the umbonal area in strophomenates (Freeman \& Lundelius 2005) in fact represents a cast of the inner side of the first-formed shell, lacking any growth marks. Observations on the morphology of the juvenile shell and pedicle sheath of Antigonambonites suggest that differentiation of the mantle lobes and secretion of a mineralised shell in that taxon were unlike the processes in Recent rhynchonelliformeans (Stricker \& Reed 1985a), taking place not simultaneously, but with formation of the ventral valve being delayed for some time. It is also likely therefore that Antigonambonites was attached to the substratum by the ventral side of the body soon after settlement, similar to the process in Recent Novocrania (Nielsen 1991). Therefore, by contrast with recently published opinions (e.g. Williams et al. 1997; Carlson \& Leighton 2001), the present authors consider that the strophomenate clade probably lacked a rhynchonelliformean type of pedicle at all growth stages.

In the Silurian (Wenlock) Eoplectodonta duvalii, a lobate first-formed shell inside the halo of the dorsal valve (Fig. 3b) is about $300-350 \mu \mathrm{m}$ wide. The presence of a primary shell layer immediately outside the halo (Fig $3 \mathrm{k}$ ) provides evidence that the halo indeed formed as a result of the initiation of the secretory regime characteristic of the adult shell. By contrast, in the ventral valve, locally preserved patches of the microgranular primary layer surround the umbonal perforation left after breakage of the pedicle sheath. Thus, observations on the first formed shell and the pedicle sheath in billingsellides and plectambonitoideans suggest distinct similarity in the early shell ontogeny of these two groups.

In Bethia serraticulma the dorsal umbonal area identified as a 'protegulum' is about $900 \mu \mathrm{m}$ wide, comparable in size with the base of the 'pedicle'. It could not have been formed by the larval mantle, but more probably represents a first-formed shell similar to that in Antigonambonites and plectambonitoideans.

\section{Conclusions}

From this discussion no evidence is seen to support the interpretation of Bethia as an orthide brachiopod. The socalled 'pedicle with preserved soft tissue' is much more likely to be a pedicle sheath with irregular concentric growth banding, as is evident in Ujukella (Fig. 2). The supposed 'pedicle rootlets' can be interpreted as outgrowths of highly modified mantle epithelium, and these mantle outgrowths would thus be the only soft tissue preserved in Bethia. The concavoconvex morphology of the Bethia shell and lack of radial ornament have no parallel in any known Silurian orthide genus; instead all characters point to a strophomenate affinity.

It is relevant to note that the Bethia shell is only $6.1 \mathrm{~mm}$ long, at a brephic or at most an early neanic growth stage. Interpretations of morphology must therefore be based on characters of immaturity and not on fully developed structures. From the comment above, the ventral 'sulcus' of Bethia is not implausibly a distinct median cleft in the first-formed shell as seen in Eoplectodonta, Jonesea, Ujekella and in many of the taxa illustrated by Freeman \& Lundelius (2005), including a range of strophomenates. The dorsolaterally placed 'incipient deltidial plates' of Bethia find no parallel in any known brachiopods, but are described as 'spine-like projections of the ventral valve, converging medially' (Sutton et al. 2005); no known taxa have deltidial plates in such a dorsolateral configuration within the pedicle opening, and these structures are far more likely to be slender chilidial plates.

In the sum of its characters, the present authors consider that Bethia is most probably allied with the plectambonitoidean strophomenates. The almost absent or incipient deltidial structures are matched in the juvenile shell of Ujukella, as well as such genera as Eoplectodonta and Jonesea known from neighbouring areas of Wenlock rocks (Bassett 1974), although such a direct comparison remains impossible. The absence of any reported radial ornament in Bethia seemingly questions such relationships, but plectambonitoideans, which have low parvicostellate sculpture, are often preserved with the outer, primary shell missing so that traces of original ornament are commonly very weak or absent. Such a primary layer was generally very thin and not always preserved in fossilised shells (Williams 1997), and this is generally the case in much of the brachiopod fauna from the offshore platform region of the Welsh Borderland, which includes the Bethia site. Some plectambonitoideans from these faunas do have weak concentric growth lamellae preserved posterolaterally (Bassett 1974). 
Distinct parvicostellate ornament may also appear at some distance from the umbo (Fig. 3b, d, k) and the space between 3-5 primary ribs in the umbonal area often lacks distinct parvicostellae, as can be seen in juvenile Eoplectodonta.

Given the overall preservation of Bethia serraticulma, and in the absence of any additional specimens, further discrimination is impossible, and at best the name exists as a taxonomic nomen dubium. It is not unlikely from the present analysis that it is a junior synonym of an already known Silurian plectambonitoidean genus and species.

\section{Dedication and acknowledgements}

It is a privilege to be able to include this paper in a volume dedicated to Alwyn Williams. His influence on understanding of brachiopod shell growth and functional morphology pervades much of what is written here. Collectively we thank the following institutions for support over many years:- National Museum of Wales, Royal Society of London, University of Uppsala, Royal Swedish Academy of Sciences, Swedish Research Council, Magnus Bergwall's Foundation and Swedish National Museum of Natural History. Many colleagues are also thanked for discussion and for supplying comparative collections, in particular Peter V. Federov (St. Petersburg State University). A European Science Exchange Programme under the auspices of the Royal Society and Royal Swedish Academy (awarded jointly to Michael G. Bassett and Lars Holmer) was especially beneficial in allowing the Cardiff and Uppsala Groups to work together. The award of a grant under the SYNTHESYS programme gave Bassett the opportunity to study comparative collections relevant to this paper at the Department of Palaeozoology in the Natural History Museum, Stockholm in February-March 2006. A SYNTHESYS award to Popov in 2005 also allowed him to study comparative Baltic material housed in the Geological Museum, University of Copenhagen.

\section{References}

Arber, M. A. 1940. The relation of the valves to the pedicle in the strophomenid brachiopods. Geological Magazine 77, 161-75.

Bassett, M. G. 1970, 1972, 1974, 1977. The articulate brachiopods from the Wenlock Series of the Welsh Borderland and South Wales. Palaeontographical Society Monographs 1-4, 1-176.

Bassett, M. G., Popov, L. E. \& Egerquist, E. 2008. Early ontogeny of some Ordovician-Silurian strophomenates: significance for interpreting evolutionary relationships within early Rhynchonelliformea. In Harper, D. A. T., Long, S. L. \& Nielsen, C.. (eds) Brachiopoda: Fossil and Recent. Fossils \& Strata 54, 13-20. Chichester: Wiley-Blackwell.

Beecher, C. E. \& Clarke, J. M. 1892. The development of some Silurian brachiopods. Memoirs of the New York State Museum 1, $1-93$.
Briggs, D. E. G., Siveter, David J. \& Siveter, Derek J. 1996. Softbodied fossils from a Silurian volcaniclastic deposit. Nature 382, $248-50$.

Bromley, R. G. \& Surlyk, F. 1973. Borings produced by brachiopod pedicles, fossil and Recent. Lethaia 6, 349-65.

Brunton, H. 1964. The pedicle sheath of young productacean brachiopods. Palaeontology $7,703-4$.

Carlson, S. J. \& Leighton, L. R. 2001. The phylogeny and classification of Rhynchonelliformea. In Carlson, S. J. \& Sandy, M. R. (eds) Brachiopods Ancient and Modern: a tribute to G. Arthur Cooper. The Paleontological Society Papers 7, 27-51.

Davidson, T. 1866-71. A monograph of the British fossil Brachiopoda. Palaeontographical Society (London), Monograph 3 (7), $1-397$.

Freeman, G. \& Lundelius, J. W. 1999. Changes in the timing of mantle formation and larval life history in linguliform and craniiform brachiopods. Lethaia 32, 197-217.

Freeman, G. \& Lundelius, J. W. 2005. The transition from planktotrophy to lecithotrophy in larvae of Lower Palaeozoic Rhynchonelliform brachiopods. Lethaia 38, 219-54.

Jin Yu-Gan, Hou Xian-Guang \& Wang Hua-Yu 1993. Lower Cambrian pediculate lingulids from Yunnan, China. Journal of Paleontology 67, 788-98.

Nielsen, C. 1991. The development of the brachiopod Crania (Neocrania) anomala (O. F. Muller) and its phylogenetic significance. Acta Zoologica Stockholm 72, 7-28.

Popov, L. E., Vinn, O. \& Nikitina, O. I. 2001. Brachiopods of the redefined family Tritoechiidae from the Ordovician of Kazakhstan and South Urals. Geobios 32, 131-55.

Popov, L. E., Egerquist, E. \& Holmer, L. E. 2007. Earliest ontogeny of Middle Ordovician rhynchonelliform brachiopods (Clitambonitoidea and Polytoechioidea): implications for brachiopod phylogeny. Lethaia 40, 85-96.

Stricker, S. A. \& Reed, C. G. 1985a. The ontogeny of shell secretion in Terebratalia transversa (Brachiopoda, Articulata): 2. Formation of the protegulum and juvenile shell. Journal of Morphology 183, 251-72.

Stricker, S. A. \& Reed, C. G. 1985b. Development of the pedicle in the articulate brachiopod Terebratalia transversa (Brachiopoda, Articulata). Zoomorphology 105, 253-64.

Sutton, M. D., Briggs, D. E. G., Siveter, David J. \& Siveter, Derek J. 2005. Silurian brachiopods with soft-tissue preservation. Nature 436, 1013-15.

Walcott, C. D. 1888. A fossil Lingula preserving the cast of the peduncle. Proceedings of the United States National Museum 11, 480.

Williams, A. 1997. Shell structure. In Kaesler, R. L. (ed.) Treatise on Invertebrate Paleontology Part H, Revised, Brachiopoda, Vol. 1, 267-320. Boulder, Colorado and Lawrence, Kansas: Geological Society of America and University of Kansas Press.

Williams, A., Carlson, S. J., Brunton, C. H. C., Holmer, L. E. \& Popov, L. E. 1996. A supra-ordinal classifcation of the Brachiopoda. Philosophical Transactions of the Royal Society, London, Biological Sciences 355, 1171-93.

Williams, A., James, M. A., Emig, C. C., Mackay, S. \& Rhodes, M. C. 1997. Anatomy. In Kaesler, R. L. (ed.) Treatise on Invertebrate Paleontology Part H, Revised, Vol. 1, 7-188. Boulder, Colorado and Lawrence, Kansas: Geological Society of America and University of Kansas Press. 